\title{
Influence of cathodic dip painting on the mechanical strength of material-adapted composite/metal joints
}

\author{
Colin Gerstenberger $\left.{ }^{1)}{ }^{*}\right)$, Tomasz Osiecki ${ }^{11}$, Tristan Timmel ${ }^{1)}$, Lothar Kroll ${ }^{1)}$ \\ DOI: dx.doi.org/10.14314/polimery.2018.11.2
}

\begin{abstract}
The flow drill joining concept (FDJ) allows the load adjusted joining of continuous fiber reinforced thermoplastics (FRTP) and metallic sheets without auxiliary joining elements. As there is no scathe done to the fiber reinforcement, a radial realignment of the fibers leads to high-strength joints with high lightweight potential. In terms of their use in automotive lightweight construction, an important requirement for joining technologies is the resistance to temperature loads and chemicals, applied in the production processes, e.g., in vehicle lacquering. Therefore, force flux aligned FDJ-joints were investigated in cross tension and shear testings, after passing through a serial cathodic dip painting (CDP) process. The results show that the CDP-treatment does not adversely affect the quasi-static properties of the tested FDJ-joints, as they resist shear loads up to $2900 \mathrm{~N}$ and cross tension loads of about $1100 \mathrm{~N}$, both, before and after the lacquering process.
\end{abstract}

Keywords: continuous fiber reinforced thermoplastics (FRTP), cathodic dip painting, joining, flow drill joining concept (FDJ).

\section{Wpływ lakierowania katodowego na wytrzymałość mechaniczną połączeń metalu z termoplastycznymi kompozytami wzmocnionymi włóknami ciągłymi}

Streszczenie: Metoda wykorzystująca wiertło tarciowe Flowdrill (flow drill joining, FDJ) umożliwia łączenie metalu z kompozytami termoplastycznymi wzmocnionymi włóknami ciągłymi (FRTP) bez udziału pomocniczych elementów łączących. W metodzie tej włókna w kompozycie nie są przecinane jak w klasycznym sposobie łączenia, ale rozszerzane, co sprawia, że połączenie cechuje się dużą wytrzymałością. Technika FDJ potencjalnie może być stosowana do konstrukcji lekkich. Ważną cechą wymaganą od wykorzystywanych w przemyśle samochodowym elementów wykonanych wg tej technologii łączenia jest odporność na obciążenia temperaturowe i chemiczne towarzyszące procesom produkcyjnym, takim jak lakierowanie katodowe (CDP). Stwierdzono, że obróbka CDP nie wpływa niekorzystnie na właściwości quasi-statyczne badanych połączeń FDJ, wytrzymują one obciążenia sił ścinających do $2900 \mathrm{~N}$ i krzyżowych do ok. $1100 \mathrm{~N}$ zarówno przed, jak i po procesie lakierowania.

Słowa kluczowe: kompozyty termoplastyczne wzmacniane włóknami ciągłymi (FRTP), lakierowanie katodowe, łączenie, metoda łączenia przy użyciu wiertła tarciowego flow drill joining (FDJ).

Due to the achievable synergy effects, continuous fiber reinforced thermoplastics are increasingly applied in automotive lightweight design [1]. Novel vehicles, like BMW i8 or Audi A6 are already in use of mounting parts, such as the diffuser frame or infotainment carriers [2,3]. In order to receive a higher level of mass reduction, the use of continuous fiber reinforced ther-

\footnotetext{
1) Chemnitz University of Technology, Faculty of Mechanical Engineering, Department of Lightweight Structures and Polymer Technology, Reichenhainer 31/33, 09107 Chemnitz, Germany.

*) Author for correspondence:

e-mail: colin.gerstenberger@mb.tu-chemnitz.de
}

moplastics (FRTP) will be extended to structural components in the near future. To fully exploit the high lightweight potential of these lightweight materials in these high-stressed areas, new material-adapted joining techniques have to be developed, since conventional joining methods - such as screwing or riveting - do not meet the needs of continuous fiber reinforced polymers in a satisfactory manner. Rather, they cause damage to the filigree fiber structure since they are based on drilled holes or joining elements with cutting edges (e.g., semi-hollow rivets). Therefore, the structural architecture of the anisotropic FRTP necessitates new and optimized solutions for a material-adapted joining with high load capacities that also consider the challenges of multi-ma- 
$60{ }^{\circ} \mathrm{C}$

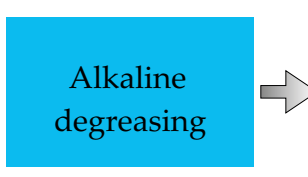

$2 \min$

$190{ }^{\circ} \mathrm{C}$

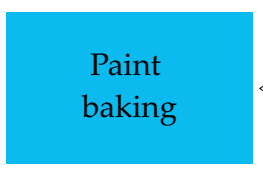

20-60 min
RT

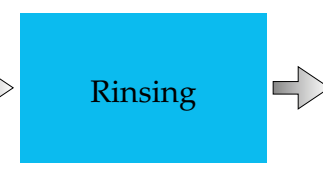

$1 \mathrm{~min}$
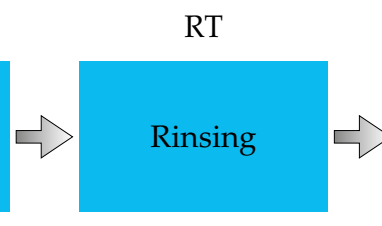

$1 \mathrm{~min}$

RT
$40{ }^{\circ} \mathrm{C}$

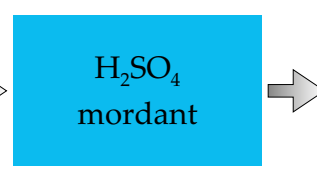

$2 \mathrm{~min}$ $27^{\circ} \mathrm{C}$

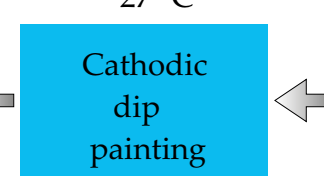

$2 \min$
RT

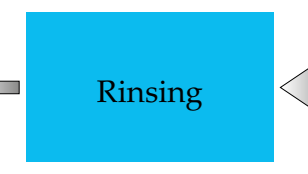

$4 \mathrm{~min}$
RT

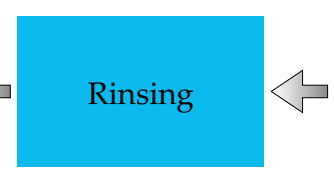

$4 \mathrm{~min}$ $40^{\circ} \mathrm{C}$

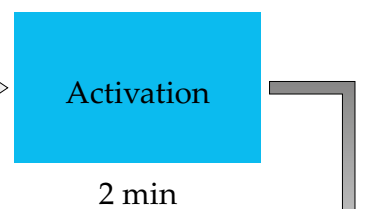

$50{ }^{\circ} \mathrm{C}$

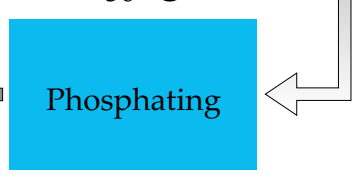

$3 \mathrm{~min}$

Fig. 1. Cathodic dip painting process

terial design between FRTP and the mostly metallic surroundings of car bodies.

In this regard, one new approach is the innovative flow drill joining concept (FDJ), developed at the Institute of Lightweight Structures (IST) of the Chemnitz University of Technology. It combines metal- and FRTP-thermoforming processes and enables a fault tolerant and reproducible joining of these various material systems. Due to an in situ fiber realignment in the FRTP load introduction zone, a high stressable force flux optimized design of the joint is achieved, whereby no additional joining element is required which suffers significant advantages in weight and costs of multi-material designs.

After numerous investigations on parameter studies, design rules and material combinations [4-6], the novel joining technique has to be qualified for the use in conventional automotive manufacturing processes. Since all car body structures are passing through a conventional automotive process chain, the joining techniques need to be resistant to all temperature loads and chemicals, applied during the production processes, e.g., in vehicle lacquering. Therefore, force flux aligned FDJ-joints were investigated in cross tension (DIN EN ISO 14272) and shear testings (DIN EN ISO 14273), before and after passing through one serial cathodic dip painting process, as shown in Fig. 1.

\section{EXPERIMENTAL PART}

\section{Materials}

In the current study, FDJ-joints made of continuous carbon fiber (HT) reinforced polyamide 6 (sheet thickness $t=2.4 \mathrm{~mm}$ ) and a representative hot-dip-coated and galvanized micro-alloyed steel (HX420LAD+Z100, $t=1.5 \mathrm{~mm}$ ) were examined. The FRTP was made of unidirectional prepreg tapes (PA6-CF60), stacked and formed to a symmetric, orthotropic $\left[(0 / 90)_{4}\right]_{\mathrm{s}}$-composite with a fiber volume content of $48 \mathrm{wt} \%$. The mechanical properties of both, the composite layers and the HX420LAD+Z100 sheets are shown in Table 1.

\section{Flow drill joining concept}

With the use of the automated FDJ process, the high lightweight potential of multi-material designs with FRTP and modern metal alloys can be utilized in a more efficient way. Compared to well known joining technologies, like riveting or bolting, there is no negative affection of the basic materials by damaging the fiber structure due to machined boreholes or cutting edges of, e.g., self-piercing rivets [4]. Furthermore, next to a renunciation of auxiliary joining elements, there are no cost-intensive operations, such as grinding, etching or degreasing, necessary.

The multi-stage joining process is shown schematically in Fig. 2 and can be described by the three main steps: 1 - plasticizing of the thermoplastic matrix, 2 - forming of a metallic bushing with a flowdrill, 3 - forming of a closing head to realize a form lock between FRTP and metal sheet.

The rotating mandrel is applied to the upper side of the metallic sheet first, and forms the required bushing throughout the plasticized FRTP in two phases afterwards. The first phase (feed rate $v_{1}$ ) serves the heat influx to increase the plasticity of the metal sheet. By forming the bushing through the previously plasticized FRTP with higher speed (feed rate $v_{2}$ ), the containing reinforcing fibers are redirected tangentially, and therefore non-destructive, around the punctiform joint. The sectioned processing with two feed rates allows a defined energy input into the metallic part, to guarantee a high quality

T a b l e 1. Mechanical properties of basic materials

\begin{tabular}{l|c|c}
\hline \multicolumn{1}{c|}{ Parameter } & PA6-CF60 & HX420LAD+Z100 \\
\hline Young's modulus $\left(E_{\mathrm{II}}\right), \mathrm{GPa}$ & 98 & 210 \\
Tensile strength $\left(\sigma_{\mathrm{m}}\right), \mathrm{MPa}$ & 1938 & $470-590$ \\
Fiber volume $(\phi), \%$ & 48 & - \\
Layer structure & {$\left[(0 / 90)_{4}\right]_{\mathrm{s}}$} & - \\
Layer thickness $\left(t_{\mathrm{L}}\right), \mathrm{mm}$ & 0.15 & 1.5 \\
Sheet thickness $(t), \mathrm{mm}$ & 2.4 & \\
\hline
\end{tabular}


1

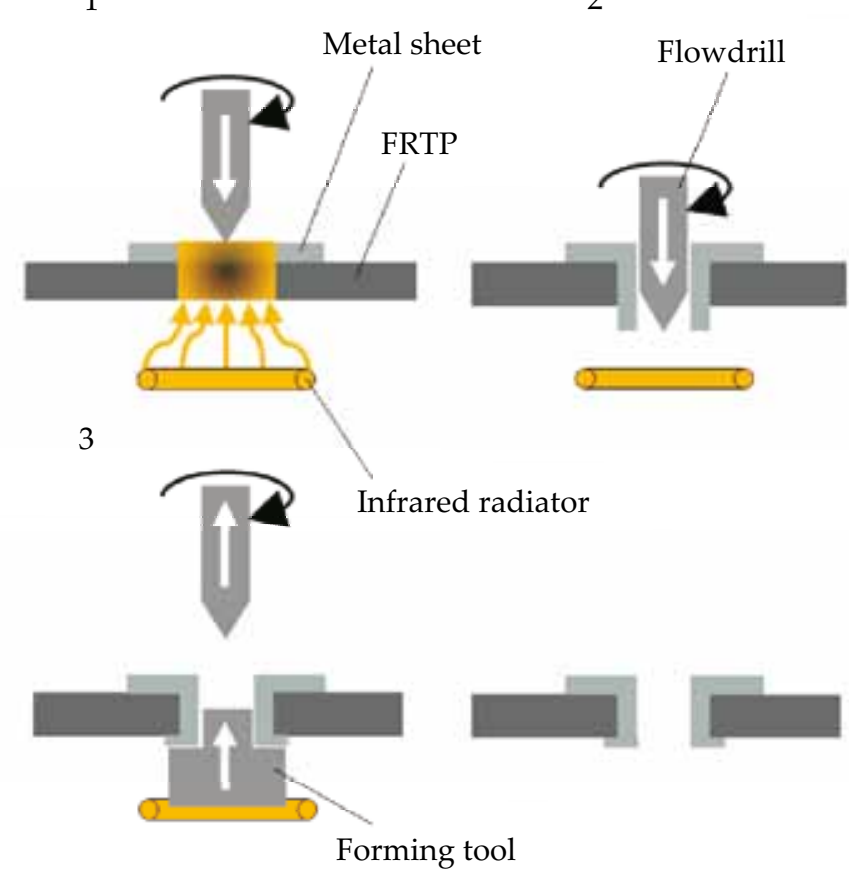

Fig. 2. Principle of manufacturing a load adjusted FDJ-joint

of the bushing for every material, and a reduction of processing time (Fig. 3). In a final step, an overleaf forming tool folds the bushing with a defined force $F_{\mathrm{U}}$ to obtain a traction and form lock between the two basic materials.

As a result of the process-induced fiber realignment and the displacement of the thermoplastic matrix, a local accumulation of material occurs in the fringe of the joining area. According to that and in contrast to established technologies, FDJ-joints contain a process-related reinforcement in the critical areas next to the joint [4].

The process parameters of the FDJ-joints used in this study are summarized in Table 2.

\section{Cathodic dip painting}

The cathodic dip painting (CDP) is an electrochemical coating process, which has proven itself a very uniform coating of metal surfaces and cavities with consistent layer thicknesses and good surface qualities in vehicle construction. The CDP primer is used to protect struc-

T a b l e 2. Process parameters of FDJ-joints

\begin{tabular}{l|c}
\hline \multicolumn{1}{c|}{ Parameter } & Value \\
\hline Sheet thickness $t, \mathrm{~mm}$ & $2.4 / 1.5$ \\
Diameter of the joint $d_{\mathrm{p}^{\prime}} \mathrm{mm}$ & 5.3 \\
Diameter of the melting area $d_{\mathrm{s}^{\prime}} \mathrm{mm}$ & 20 \\
Rotational speed of flowdrill $n, \mathrm{rpm}$ & 3000 \\
Feed rate $v_{1^{\prime}} \mathrm{mm} / \mathrm{min}$ & 300 \\
Feed rate $v_{2^{\prime}} \mathrm{mm} / \mathrm{min}$ & 1300 \\
Change-over point $l, \mathrm{~mm}$ & 1.0 \\
Forming force $F_{\mathrm{U}^{\prime}} \mathrm{kN}$ & 18 \\
\hline
\end{tabular}

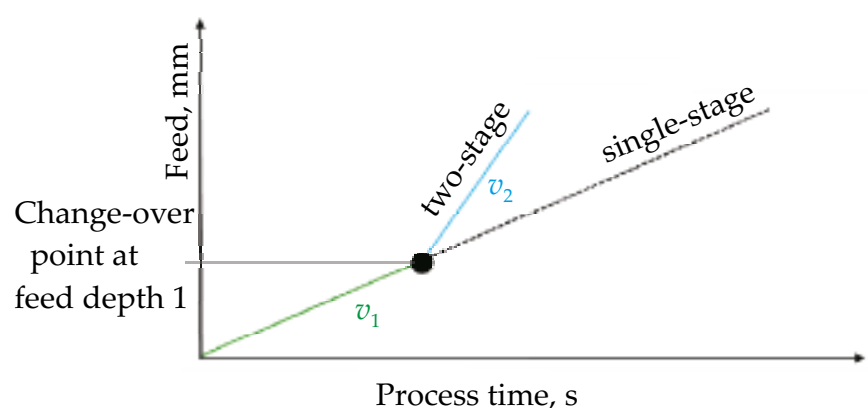

Fig. 3. Feed rates $v$ and change over point 1

tures against corrosion and serves as an adhesion base for subsequent coatings [7].

Due to the inconsistent temperature profile, with top temperatures in the range of $130^{\circ} \mathrm{C}$ to $190^{\circ} \mathrm{C}$, and the highly divergent coefficients of thermal expansion in FRTP and metals, the baking of lacquers represents a particularly critical load for joints in multi-material design. Thus, thermally induced residual stresses can lead to damages if the joining technology is not suitable for CDP treatments.

The traversed temperature profile of the tested CDP process shows an approximately 35 minutes lasting, steady heating of the specimen. As to be seen in Fig. 4 the duration of the baking process with a maximum temperature of $190{ }^{\circ} \mathrm{C}\left( \pm 2.8^{\circ} \mathrm{C}\right)$ takes about 20 minutes, followed by a rapid cooling to $29^{\circ} \mathrm{C}\left( \pm 3.9^{\circ} \mathrm{C}\right)$ within about 5 minutes.

\section{Methods of testing}

The conducted experiments and specimen geometries are based on the standard testings for resistance spot-welded joints: DIN EN ISO 14272 and DIN EN ISO 14273 (Table 3). Due to its importance for the automotive industry, resistance spot-welding has a broad normative background and is accordingly well documented in terms of testing procedures. Specimen shapes and test parameters can be transferred to the examination of other punctiform joints, which is why they are often used for comparative studies. Unlike material testing the investigation of punctiform joints is mostly limited to the determination of maximum forces.

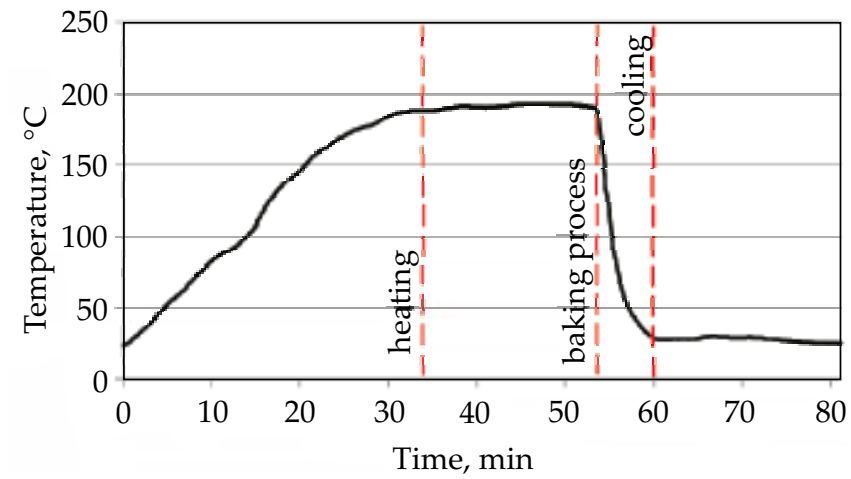

Fig. 4. Temperature profile of tested CDP treatment-paint baking process 
T a b l e 3. Specimens according to DIN EN ISO 14272 and DIN EN ISO 14273

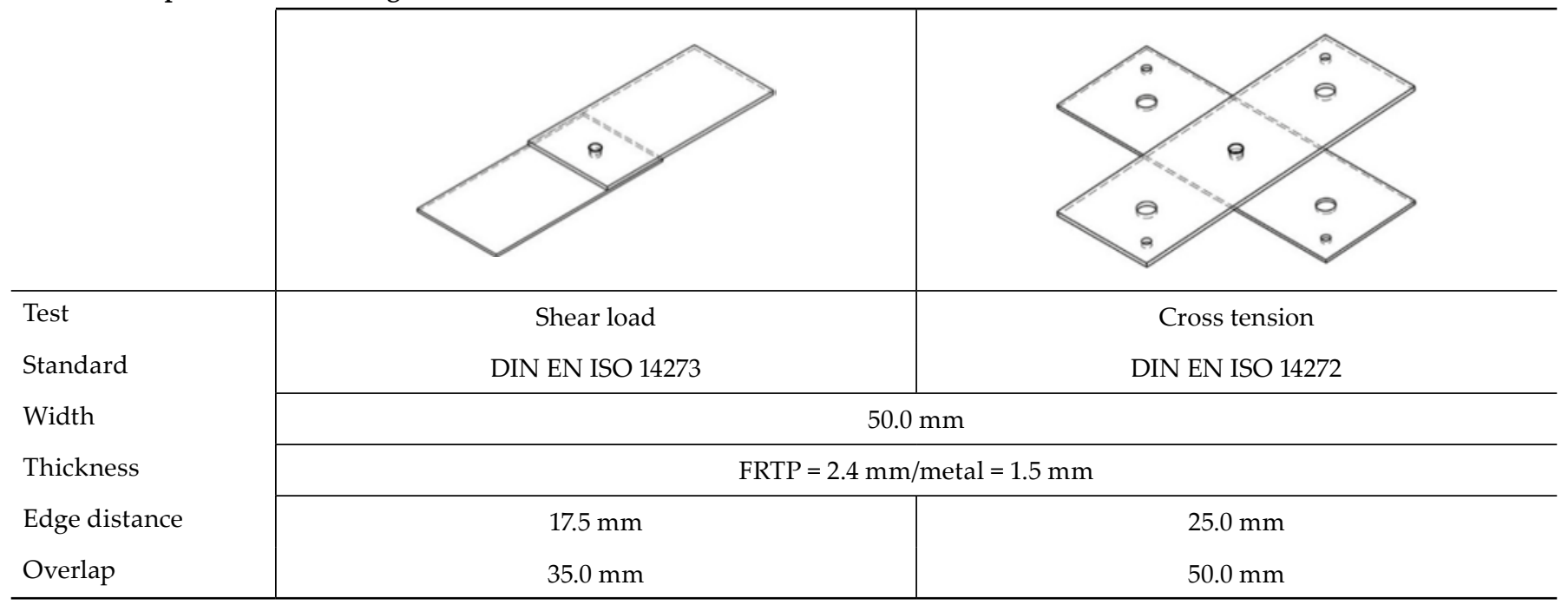

The investigations of this study are quasi-static (testing speed $2 \mathrm{~mm} / \mathrm{min}$ ) and were carried out on a tensile testing machine according to DIN 51220 with measuring equipment according to DIN EN ISO 7500-1. The loads were increased slow, shock-free and steady until failure of the specimens. The room temperature was $23{ }^{\circ} \mathrm{C}$ with a humidity of 50 \%, as mentioned in DIN EN ISO 291.

\section{RESULTS AND DISCUSSION}

The results of the cross tension and shear testings in accordance to DIN EN ISO 14272 and 14273 confirm the high strength and strong resistance of PA6-CF-based FDJ-joints against thermal and medial loads within the cathodic dip painting process. A comparison to specimens in untreated conditions shows no significant impact of the CDP process on the tolerable quasi-static shear and cross tension forces (Fig. 5). The findings are underlined by [3], where it is said that the fiber-dominated properties of PA6-based FRTP are not affected by CDP treatment. A presumed effect on the maximal tolerable forces - in consequence of adhesive CDP-depositions between FRTP and metal - could also not be confirmed because the strength of the FDJ-joints superimposes the properties of the cataphoresis coating.

\section{CONCLUSIONS}

In terms of their use in automotive lightweight construction, an important requirement for joining technologies is the resistance to temperature loads and chemicals, applied in the production processes, e.g., in vehicle lacquering. Therefore, force flux aligned FDJ-joints were investigated in cross tension and shear testings, after passing through a serial cathodic dip painting process. The results show that the cathodic dip painting process does not adversely affect the static properties of the tested FDJ-joint and confirm the high strength and strong resistance of PA6-CF-based FDJ-joints against thermal and medial loads. In further investigations, the effects on fatigue strength will be examined.

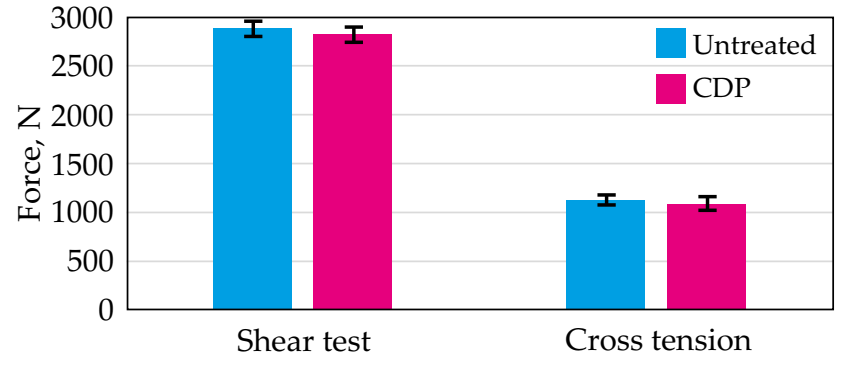

Fig. 5. Results of shear and cross tension tests (5 specimens per each test condition)

\section{ACKNOWLEDGMENTS}

The presented studies were performed as part of a pre-investigation within the Federal Cluster of Excellence EXC 1075 "MERGE Technologies for Multifunctional Lightweight Structures" and supported by the German Research Foundation (DFG) to explore integrative processes with plastic/metal composites. Financial support is gratefully acknowledged.

\section{REFERENCES}

[1] Goede M., Stehlin M., Rafflenbeul L. et al.: European Transport Research Review 2009, 1, 5. http://dx.doi.org/10.1007/s12544-008-0001-2

[2] Osiecki T., Gerstenberger C., Hackert A. et al.: Key Engineering Materials 2017, 744, 311.

ISBN-13 978-3-0357-1116-5.

http://dx.doi.org/10.4028/www.scientific.net/ KEM.744

[3] Grätzl T., Schramm N., Kroll L.: "Influence of the Cathodic Dip Painting Process on Fibre-Reinforced Thermoplastic Composites", Proceedings of the $3^{\text {rd }}$ International Conference \& Exhibition on Thermoplastic Composites ITHEC, Bremen (Germany), 1112. 10. 2016. ISBN: 978-3-933339-29-4.

[4] Seidlitz H.: "Entwicklung von kraftflussgerechten Verbindungstechniken für Mischbauweisen mit thermoplastischen Faserverbunden und Metallen", 
Dissertation, TU Chemnitz, 2013. Verlag Dr. Hut. ISBN: 978-3-8439-0961-7.

[5] Seidlitz H., Ulke-Winter L., Kroll L.: Journal of Engineering 2014, 2014, ID 958501.

http://dx.doi.org/10.1155/2014/958501

[6] Seidlitz H., Ulke-Winter L., Gerstenberger C., Kroll L.: Open Journal of Composite Materials 2014,
4 (3), 157. ISSN 2164-5612.

http://dx.doi.org/10.4236/ojcm.2014.43018

[7] Gerstenberger C., Osiecki T., Kroll L. et al:: Archives of Civil and Mechanical Engineering 2016, 16, 467.

http://dx.doi.org/10.1016/j.acme.2016.03.001

Received 23 XII 2017. 